\title{
Landscape planning for a safe city
}

\author{
Mikiko Ishikawa \\ Environmental Information, Keio University, Endoh Fujisawa City, Kanagawa, Japan
}

\begin{abstract}
To create a safe city free from natural disasters has been one of the important criteria in city planning. Since large cities have suffered from large fires caused by earthquakes, the planning of open spaces to prevent the spread of fires is part of the basic structure of city planning in Japan. Even in the feudal city of Edo, the former name of Tokyo, there had been open spaces to prevent fire disasters along canals and rivers. This paper discusses the historical evolution of open space planning, that we call landscape planning, through the experiences in Tokyo, and clarifies the characteristics and problems for achieving a safe city.
\end{abstract}

Key words fire disasters - urban planning - safe city park system - fireproof city

\section{Park system introduced as the infra- structure for a safe city (1923-1950's)}

In Japan, the first city planning law was enacted in 1919. However, ironically enough, the first comprehensive city plan was carried out as the reconstruction plan after the Kanto big earthquake which occurred in 1923. About 1484000 people were affected, whereas the total population in Tokyo at that time was 2309000 . The most important goal of this project was how to build a fireproof city. Considering economic and cultural standards, it was impossible to construct stone or brick buildings. The government chose the method of separating dense urban areas by open spaces such as parks and parkways. People knew the fact that trees and open spaces prevented the spread of fires, since 1570000 people escaped into parks and saved their lives.

Mailing address: Prof. Mikiko Ishikawa, Environmental Information, Keio University, 5322 Endoh Fujisawa City, Kanagawa Prefecture 252-8520, Japan; e-mail: mikiko@sfc.keio.ac.jp
This method was called the «park system». The park system is a simplified terminology of the «parks, parkways and boulevards system», rapidly developed in the United States after the big fire of Chicago in 1871. Figure 1 shows the original reconstruction plan of the Kanto Big Earthquake, and large parks originated from the feudal stocks were deliberately connected with major roads. Although the plan was reduced for financial reasons, 3 parks, 52 children's playgrounds and 52 streets (width 22-73 m, total length $117065 \mathrm{~m}$ ) were created. The fundamental structure of modern Tokyo was thus created.

\section{The park system as the reconstruction project (1950-1960's)}

The second wave of landscape planning for a safe city was the reconstruction project after World War II. In 1946, the Special City Planning Law for the reconstruction was enacted. The characteristic of this law was to establish the basic land use plan. The city planning areas were divided into three zones: urban zone, green belt zone, and urbanization pending zone. Within the urban zone, building a fireproof city was the main theme. Therefore the park system and the land 


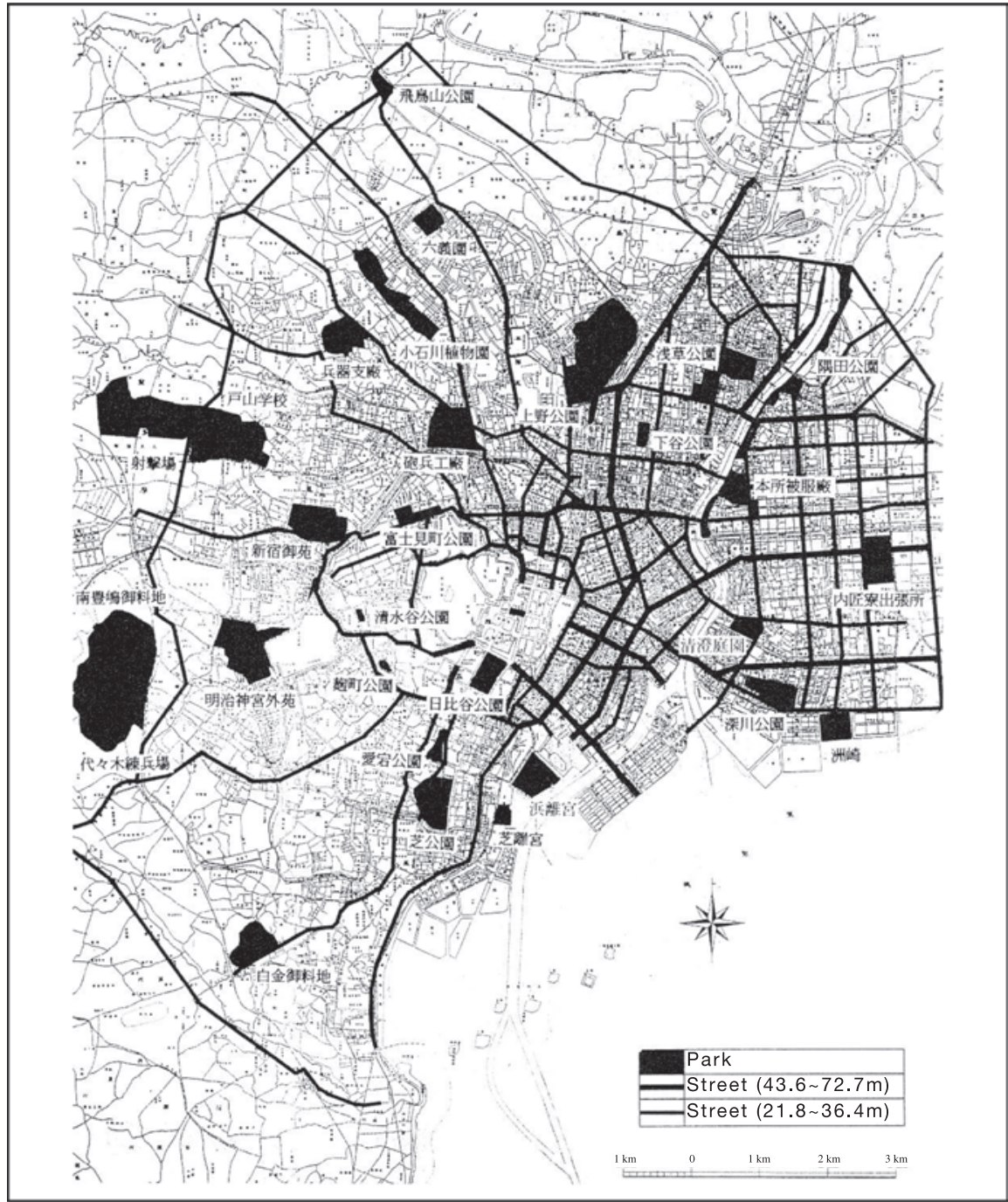

Fig. 1. Reconstruction plan after Kanto Big Earthquake (1923) (Ishikawa, 2001).

readjustment project were adopted as the basic method of reconstruction (fig. 2). The greenbelt zone was designated along the fringe area of 23 wards to prevent urban sprawl (fig. 3). However, rapid urbanization took place and the reconstruction projects were decreased. The land readjustment area was reduced from 20130 ha to 1652 ha. The greenbelt zone was reduced from
18010 ha to 9870 ha in 1955 , and after 29 modifications, finally abolished in 1969. Figure 4 shows the present location of the dense wooden housing areas. It extends over a radius of 15-20 $\mathrm{km}$ from Tokyo station. This area is the middle area between the land readjustment zone and the greenbelt zone, where no comprehensive policies were implemented. 


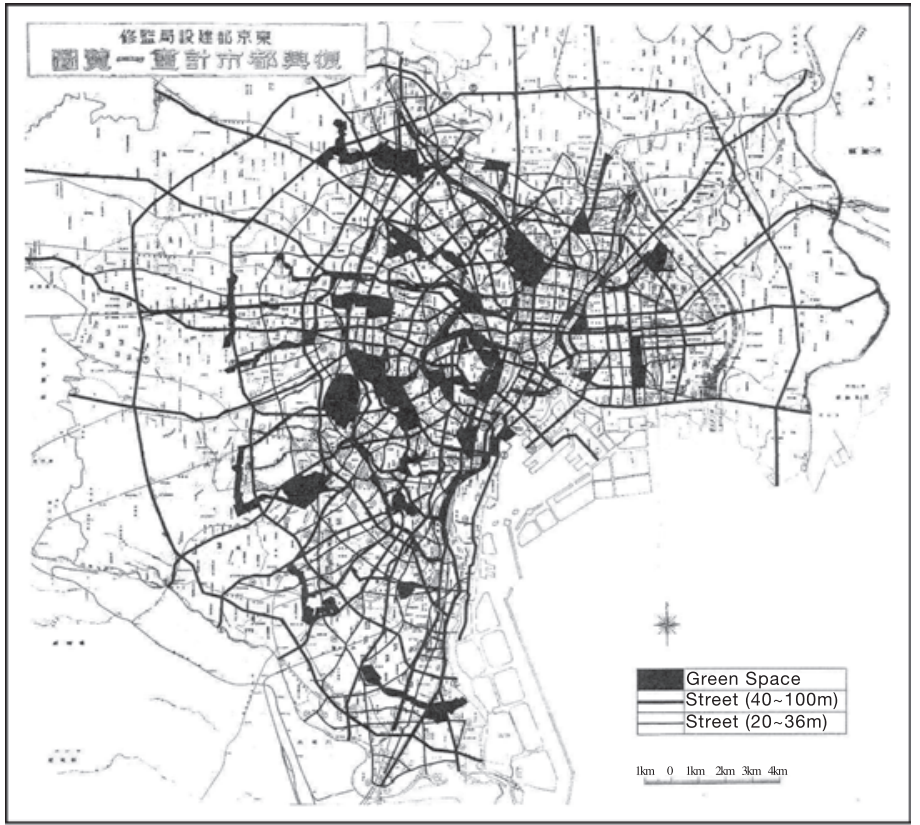

Fig. 2. Reconstruction plan after the World War II (1946) - Park System (Ishikawa, 2001).

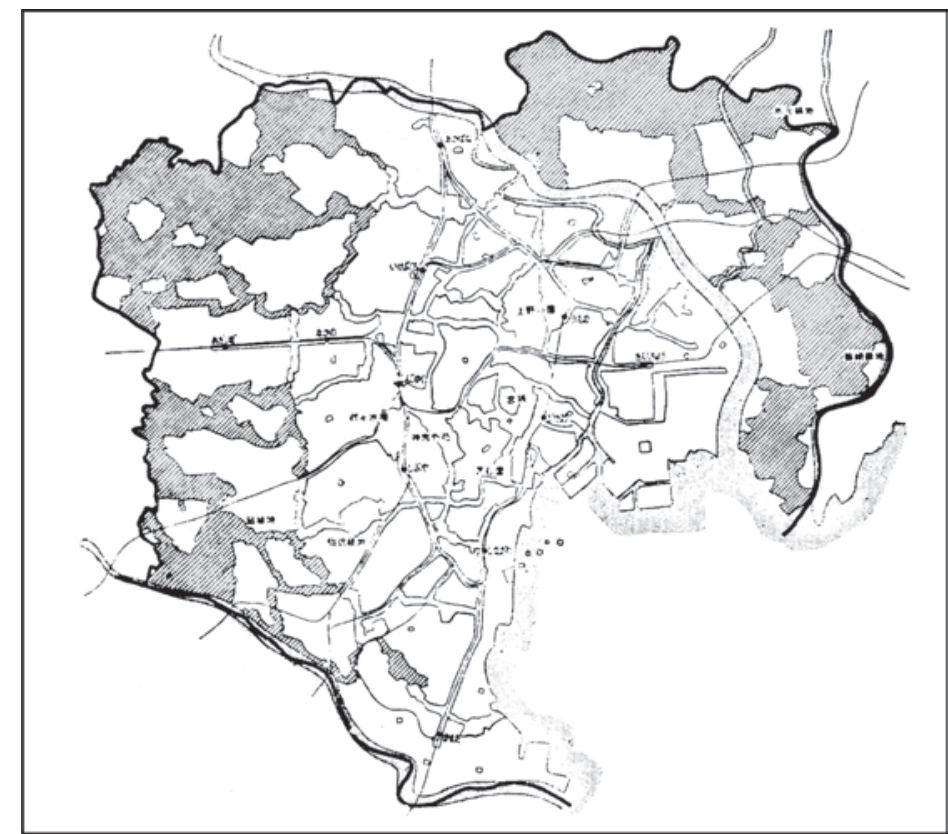

Fig. 3. Reconstruction plan after the World War II (1948) - Green Belt (Ishikawa, 2001). 


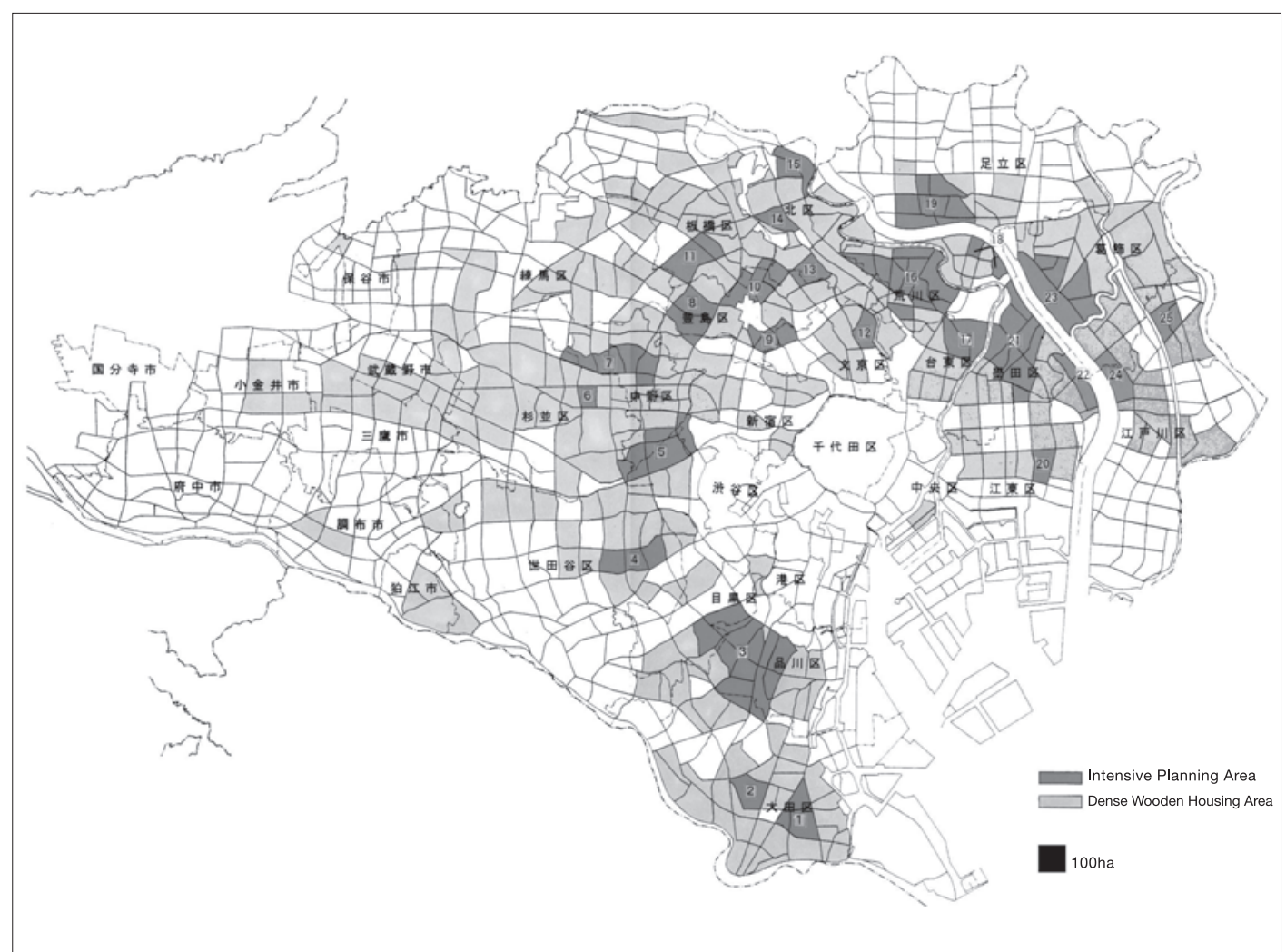

Fig. 4. Dense wooden housing areas and intensive district for Safe Living Environment Zone Project in Tokyo (Tokyo Metropolitan Government, 1996).

\section{Hanshin-Awaji Big Earthquake and its reconstruction projects $(1995-2002)$}

The third wave was the effect of the HanshinAwaji Big Earthquake in 1995. 110117 houses were completely destroyed and 6398 people died. Small parks and open spaces in dense urban areas played important roles in preventing the spread of fires and became the immediate refuges for affected people (pictures 1 to 3). Table I shows how people used small parks immediately after the earthquake. It has been said that small parks were not important when the big earthquake and fires occurred. However, their actual use had proved the importance of community-oriented small parks.

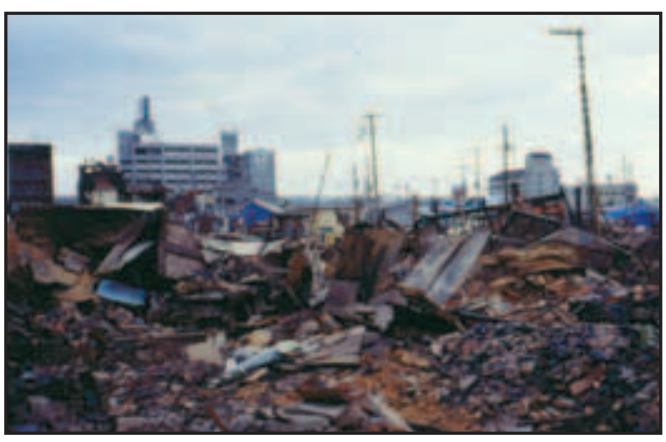

Picture 1. Burned down area of former dense wooden houses (Hanshin-Awaji Big Earthquake 1995) (by M. Ishikawa). 


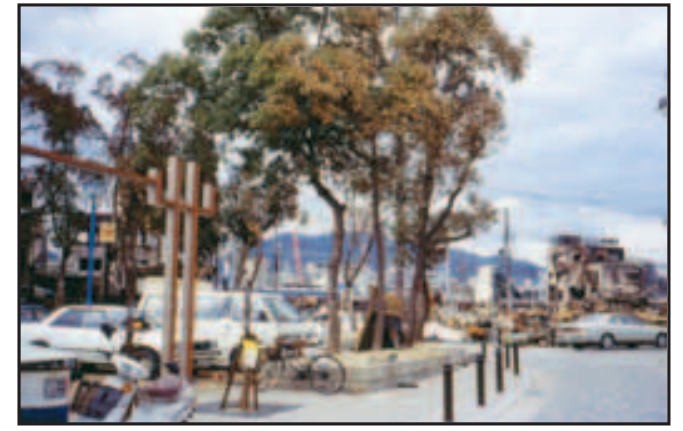

Picture 2. Small parks prevented the extension of fires in dense wooden housing areas (Hanshin-Awaji Big Earthquake 1995) (by M. Ishikawa).

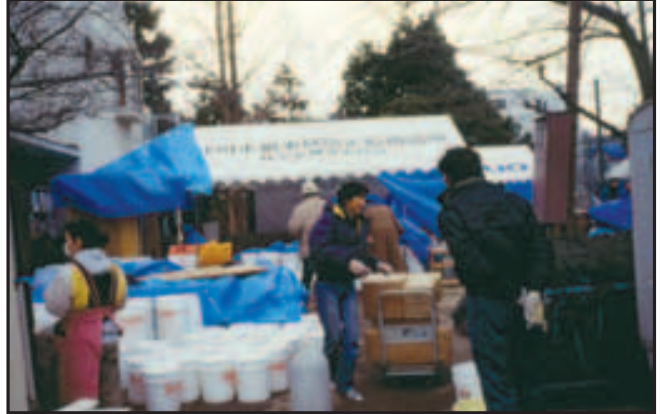

Picture 3. Small parks became immediate refuges and supporting centers for people (Hanshin-Awaji Big Earthquake 1995) (by M. Ishikawa).

Table I. The use of parks in Kobe City after the Hanshin-Awaji Big Earthquake (January 24-25, 1995). The purpose of park usage overlaps.

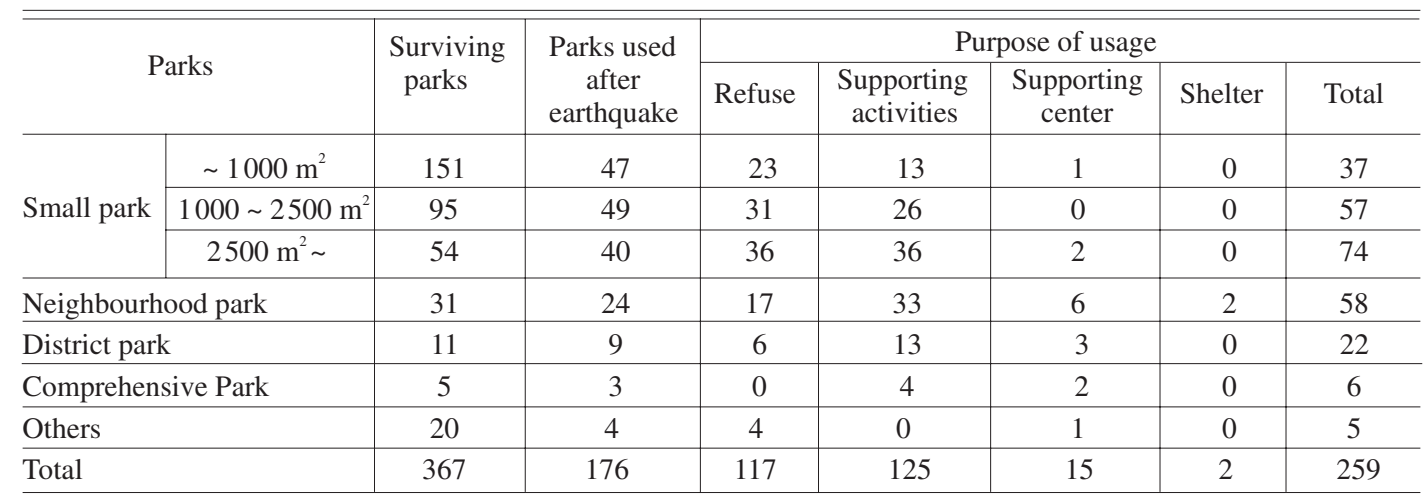

During the reconstruction process after the Hanshin-Awaji Big Earthquake, diverse reconstruction projects were implemented, involving citizen participation. The basic structure was chosen to enforce the park system, and in addition to this, many different community parks were created. Figure 5 is the reconstruction plan in the Matsumoto district in Kobe. In this district, $80 \%$ of wooden houses were burned down. Citizens had a strong opinion that if there had been water sources in the neighborhood, the damage would have been decreased. In May 1995, right after the big earthquake, the Matsumoto Area Community Development Council was established and the first plan of a Community Development Proposal was submitted to the City in December 1995. In 1996, the Detailed District Plan was determined, and the actual reconstruction process started. The characteristic of this plan is that it introduced a small stream in the middle of the district. The crucial issue for the implementation of this plan was the source of water for this stream. This problem was solved by utilizing the high treated sewage water from new towns behind the Rokko Mountains. This is a new collaboration between the existing old town and the new town. In November 2000, the construction of the stream started and the project was completed in Sep- 


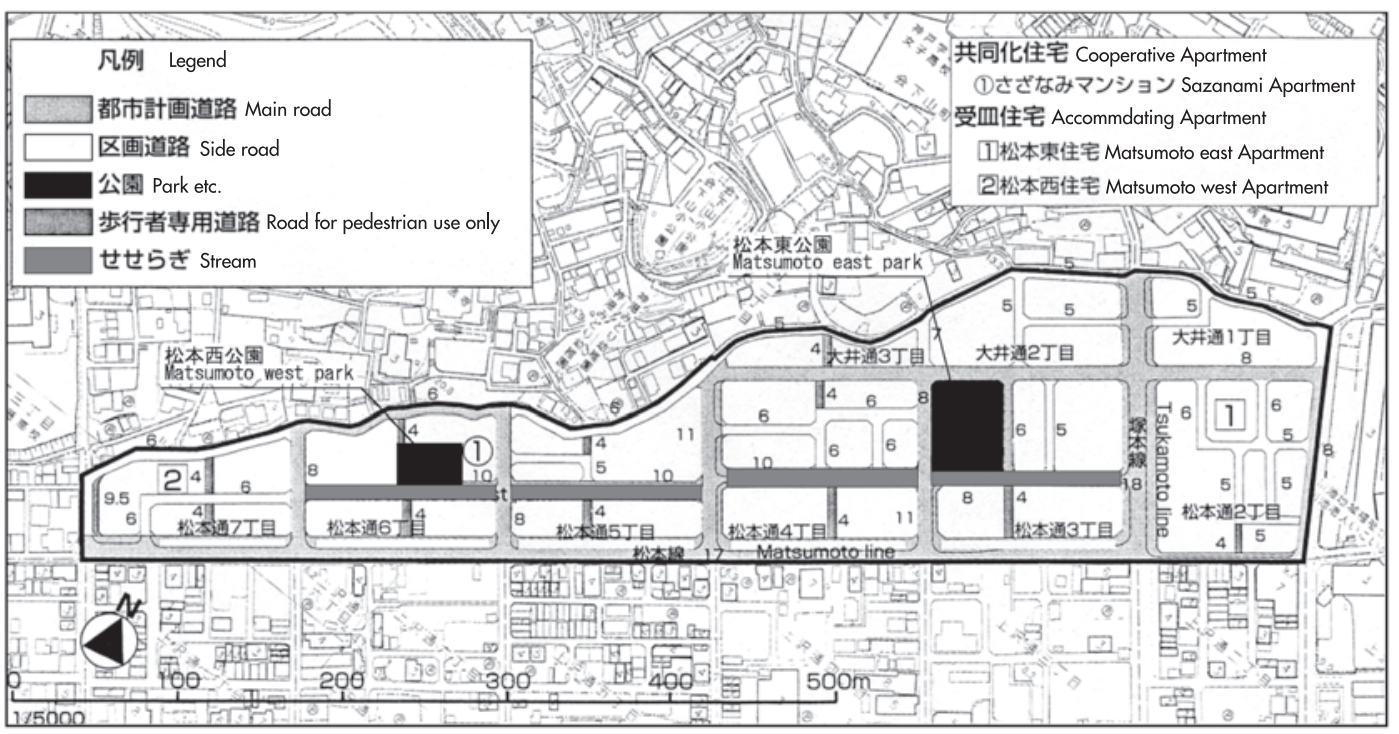

Fig. 5. The reconstruction plan of Matsumoto area in Kobe (Matsumoto Area Community Development Council and Kobe City, 2001).

tember 2001. It took 6 years, but finally the new community park for safe city was implemented.

\section{Safe Living Environment Zone and revitalization of park system in Tokyo}

Soon after the Hanshin-Awaji Big Earthquake, the Tokyo Metropolitan Government and 23 Wards carried out a comprehensive study and designated the intensive planning area where immediate actions for safe city were required (fig. 4). The basic strategy was to create the «Safe Living Environment Zone» surrounded by main roads or rivers. The Safe Living Environment Zone is divided into sub-units, and in the middle, small parks or open spaces are planned as centers of the community. Water tanks and food were provided for emergencies. Figure 6 shows the plan of the Safe Living Environment Zone in Higashi-Ikebukuro, Toshima Ward, where dense wooden houses were concentrated. It is hard to create a large park in this area. The characteristic of this plan is to open the cemetery as a park- like open space. Also, by transforming 2 story old wooden houses into 5-6 story condominiums, it will become possible to create new small parks as a core of the community and a safe city.

Another important project for a safe city in Tokyo is to re-enforce the metropolitan park system. Figure 7 is the structure of green and water corridors in metropolitan Tokyo, and fig. 8 is focused on the central 23 Wards area.

The core of Tokyo is the Imperial Palace area where Tokyo has had a huge stock of open spaces since the Edo era. These open spaces are used as the site of public institutions, parks and the Imperial Palace. It is important to create a new public access to contribute to a safe city as refuges for many workers in the central business district.

The second target of the new park system is the waterfront area along Tokyo Bay. Because of drastic changes in the function of Tokyo Port, the land-use of waterfront areas shifted from industrial uses to commercial and residential uses. Therefore, the basic policy of the new park system is to create natural environments along the seashore, and to establish a large park which 


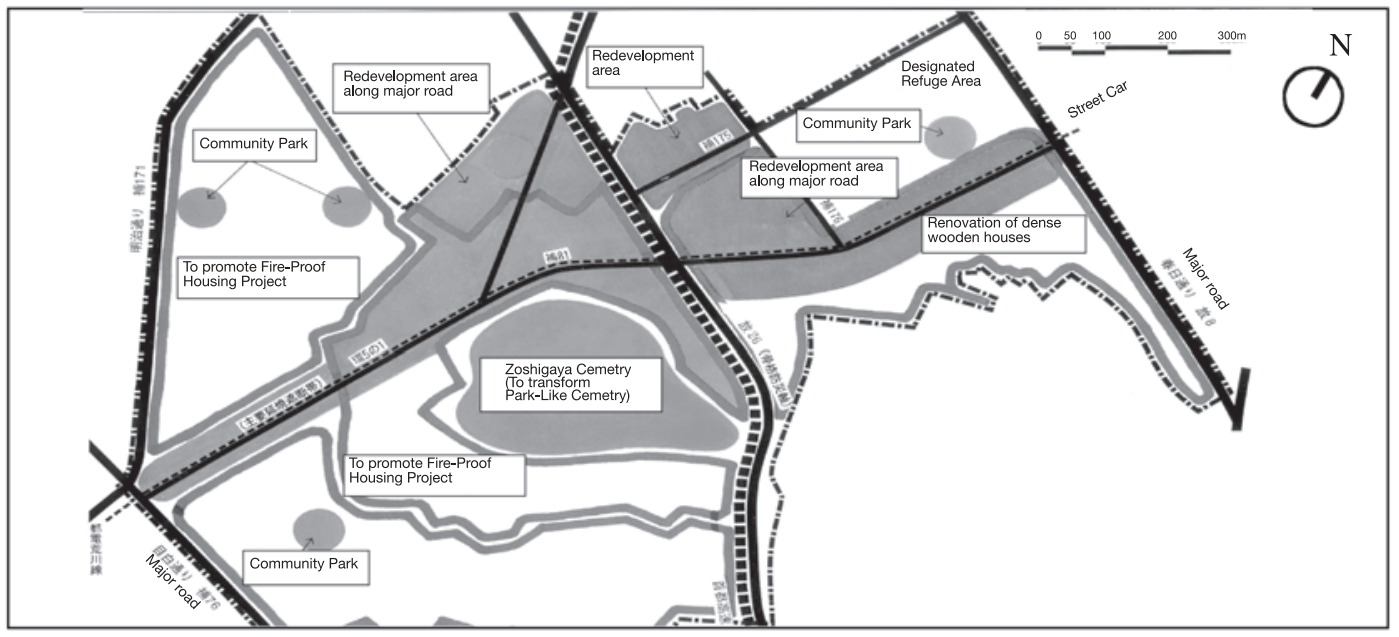

Fig. 6. The plan of the intensive district for Safe Living Environment Zone (Tokyo Metropolitan Government, 1996).

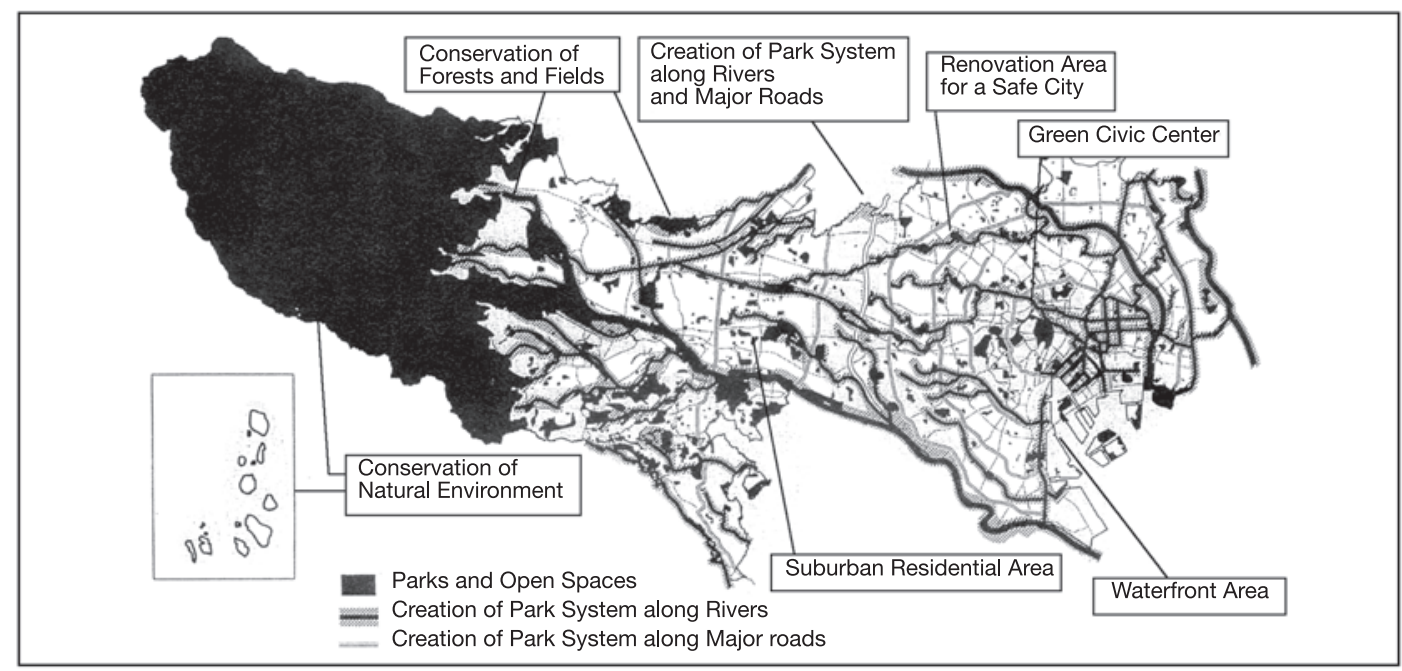

Fig. 7. The Park System in Tokyo (Tokyo Metropolitan Government, 2001).

will serve for refuges and the supporting center if Central Tokyo is damaged. The third target of the new park system for a safe city is to create open space corridors along riversides. During the rapid economic growth in the 1960-1970's, the rivers in Tokyo were completely neglected.
Figure 9 shows the reclaimed rivers in Tokyo. Picture 4 shows the worst case of riverside landscape in Tokyo. Series of projects for revitalization along the riverside have been implemented. Picture 5 is the super bank project along the Arakawa River. This project has three pur- 


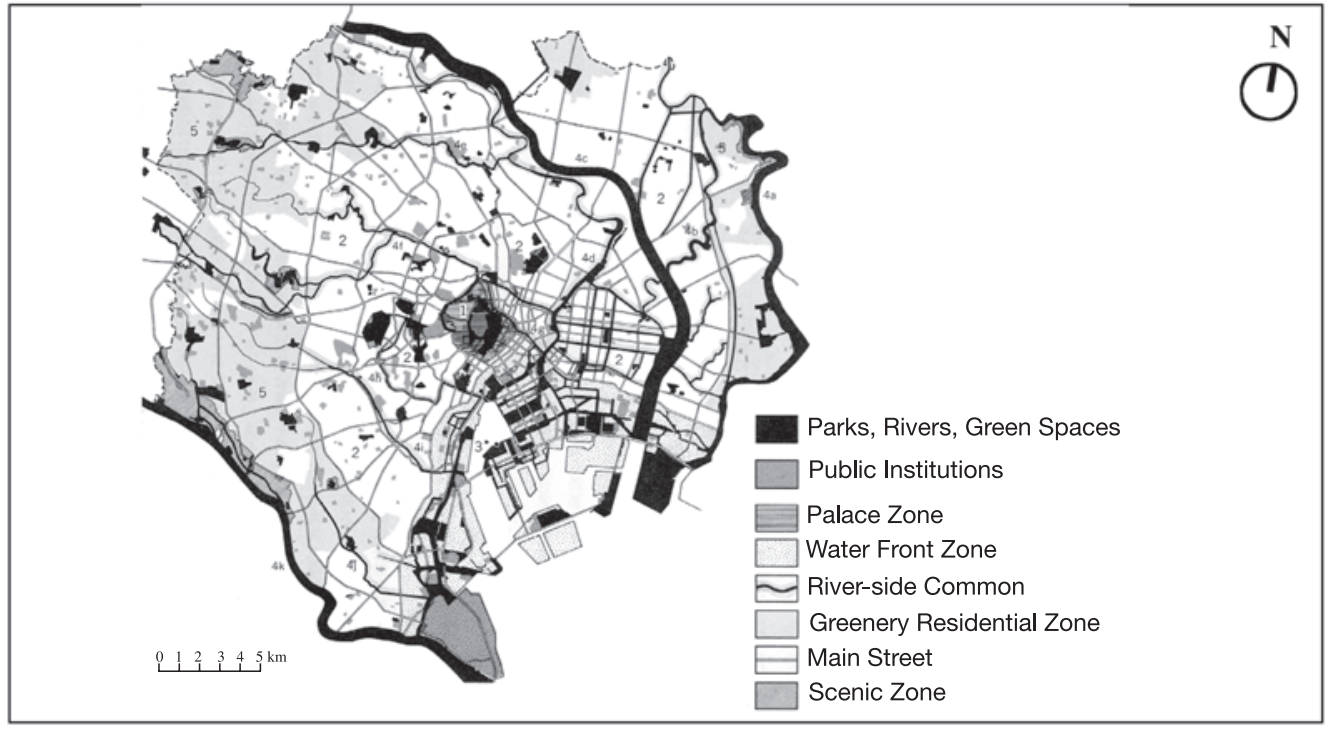

Fig. 8. The Park System in 23 Wards in Tokyo (Ishikawa, 2001).

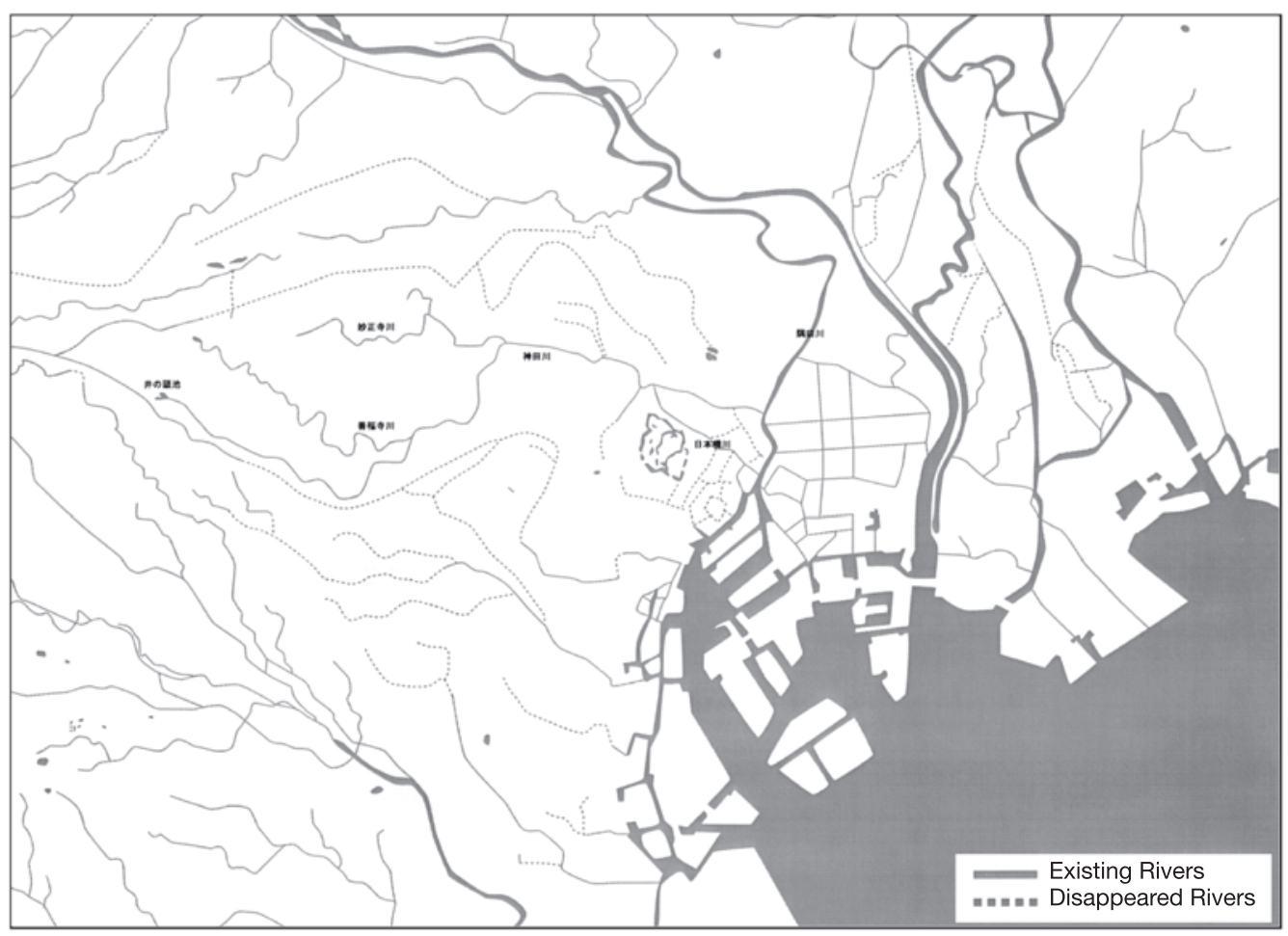

Fig. 9. Rivers in Tokyo (Ishikawa et al., 2001). 


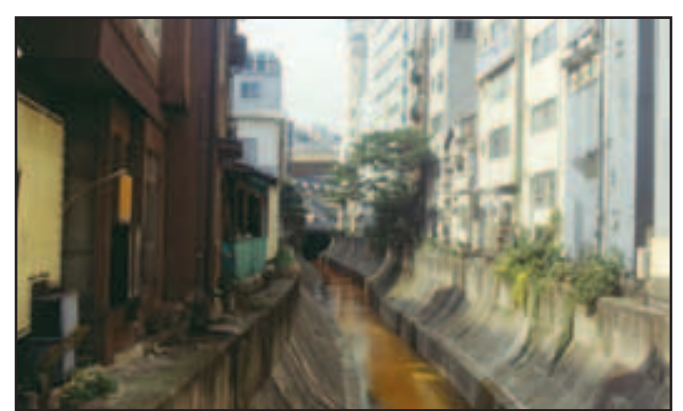

Picture 4. River surrounded by buildings (Shibuya River, Tokyo) (by M. Ishikawa).

poses. The first is to strengthen the function of the riverbank, the second is to redevelop the dense wooden industrial area into a residential area, and the third is to create river-side community parks.

\section{Conclusions}

This paper has discussed the historical evolution of landscape planning for a safe city. In Japan, green open spaces and water have been regarded as the essential factors for a safe city. We have faced the era of the revitalization of inner cities. To introduce a new park system is the key issue to achieve a safe city.

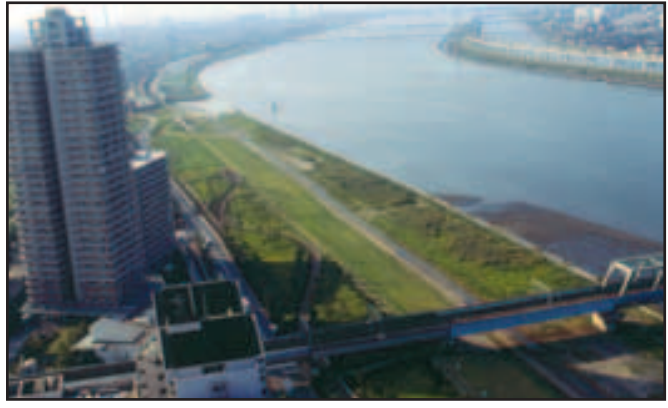

Picture 5. Super bank project along the Arakawa River in Tokyo (by M. Ishikawa).

\section{REFERENCES}

ISHIKAWA, M. (1996): The park system and its role as prevention disasters planning, 31st Japan City Planning Conference, 133-138.

ISHIKAWA, M. (2001): City and Green space, (Iwanami Co. Ltd).

ISHIKAWA, M. et al. (2001): Revitalization of Inner City Tokyo and Kanda River.

Matsumoto Area Community Development Council AND Kobe CiTy (2001): The Reconstruction Plan in Matsumoto Area.

SATO, A. (1977): The Historical Evolution of Parks and Open Spaces Planning in Japan (City Planning Associates Inc).

TOKYO METROPOLITAN GOVERnMENT (1996): The Master Plan for Safe City.

TOKYO METROPOLITAN GOVERNMENT (2001): The Vision for Tokyo in 2020. 